\title{
How teachers contribute to student success in completing study programs
}

\author{
Ecaterina Sarah Frăsineanu, Vali Ilie
}




\title{
How teachers contribute to student success in completing study programs
}

\author{
Ecaterina Sarah Frăsineanu ${ }^{a *}, V$ ali Ilie ${ }^{b}$ \\ ${ }^{a}$ University of Craiova, Department of Teacher Training, 13, A.I. Cuza Street, \\ Craiova, 200585, Romania \\ ${ }^{b}$ University of Craiova, Department of Teacher Training, 13, A.I. Cuza Street, \\ Craiova, 200585, Romania \\ *Corresponding author: ecaterina.frasineanu@edu.ucv.ro
}

\section{Abstract}

Keywords:

students; professors; success; support; objectivity.
The present study analyzes the contribution that teachers, as important pedagogical factors, have in achieving success in the academic learning of students. With age, there comes a greater autonomy of the educated, and during the university studies, a maximum of the students' level of acquisitions is reached. Even if the most important factors in attending and completing studies are internal, and success is a relative, difficult situation to quantify, it is necessary to analyze it objectively, identifying the students' perceptions of the external support from the teachers. From an applicative point of view, our contribution consisted in verifying the extent to which the communication and didactic evaluation components are valued, by organizing focus groups, by applying appreciation scales to a sample of students preparing to become teachers, at the University of Craiova. The subjects responded to the request to perform reflective-appreciative exercises on themselves and on the activity of their teachers in the academic year 2020-2021. They indicated the degree of satisfaction they attribute to the way they were helped in: conducting didactic communication, experiencing the feeling of belonging to the university environment, applying a correct evaluation, heading towards academic success. The ways in which teachers contribute to the success of their students have proven their usefulness and can be transformed into directions of action. Teachers make it easier for young people or adults in the university environment to make the most of their potential, both through quality teaching and through encouraging evaluation.

\section{Zusammenfasung}

\section{Schlüsselworte:}

Studenten; Lehrer; Erfolg;

Unterstützung; Objektivität.
Diese Studie analysiert den Beitrag, den Lehrende als wichtige pädagogische Faktoren zum Erfolg des akademischen Lernens von Schülern haben. Mit zunehmendem Alter besteht eine größere Autonomie der Ausgebildeten und während des Studiums wird ein Höchstmaß an Erwerb von Studierenden erreicht. Auch wenn die wichtigsten Faktoren in Beteiligung und Abschluss des Studiums, interner Natur sind und der Erfolg eine relative Situation ist, die schwer zu quantifizieren ist, ist es notwendig, diese objektiv zu analysieren und die Wahrnehmung der Studierenden an die externe Unterstützung durch die Lehrkräfte zu identifizieren. Aus applikativer Sicht bestand unser Beitrag darin, die Wertschätzung der kommunikativen und didaktischen Evaluationskomponente zu überprüfen, durch die Organisation von Fokusgruppen, durch die Anwendung von Bewertungsskalen an einer Stichprobe von Studenten, die sich darauf an der Universität von Craiova vorbereiten, Lehrer zu werden. Die Probanden kamen der Aufforderung nach, im Studienjahr 2020-2021 reflexiv-anerkennende Übungen an sich selbst und an der Tätigkeit ihrer Lehrenden durchzuführen. Sie gaben an, wie zufrieden sie waren, mit der Art der Förderung sie bekommen haben in : die Entwicklung der didaktischen Kommunikation, das Zugehörigkeitsgefühl zum universitären Umfeld, die Anwendung einer korrekten Evaluation, die Orientierung am Studienerfolg. Die Wege, auf denen, die Lehrkräfte zum Erfolg der Schüler beitragen, haben sich Ihre Nützlichkeit bewährt und kann in Handlungsanweisungen umgesetzt werden. Lehrerinnen und Lehrer erleichtern es jungen Menschen oder Erwachsenen im akademischen Bereich, ihr Potenzial voll auszuschöpfen, sowohl durch einen qualitativ hochwertigen Unterricht als auch durch die Förderung der Evaluation.

\section{Introduction. Quantifying academic success}

Success is a very relative term, because it is best known to the person experiencing it. In the academic environment, it does not necessarily mean obtaining high grades. Failure has a strong negative emotional connotation, the term unsuccess being preferred, because it implies the possibility of recovery. We understand that unsuccess is no longer "only a pedagogical problem, but a social one, too", as Sălăvăstru (2004, p.229) pointed out, a problem of adapting to the actual tasks, relationships and institutional environment. It can exhibit itself in simple or serious forms, the serious ones determining the abandonment of studies. The complementarity of the internal-external determinants, of the subjective- 
objective perceptions of success is often affirmed, especially when success is related to the completion of study programs and the meaning extends to professional success: „Measures of professional success provided by surveys on higher education graduates can be divided into objective (eg income or professional position) and subjective (eg job satisfaction, reported use of knowledge and skills, work autonomy) indicators." (Schomburg, 2007, p. $35)$.

In students, the study program consists of correlated curricular units of teaching-learningresearch-practical applications and assessment, which provide a certified qualification, and the Romanian Education Law (2011), with subsequent amendments, shows that a student's academic success along a study program is determined by summative assessments under the form of an exam and by continuous assessment. Statistically, a large number of Romanian students complete their studies successfully. In the Periodic Public Report of the Romanian Ministry of Education, having as reference the year 2017-2018, we find that, out of a total of 405.6 thousand students enrolled at the beginning of 2016/2017 in the undergraduate university education, in the records at the end of the year they found 367.9 thousand $(90.7 \%)$. Of these, 344.5 thousand $(84.9 \%)$ promoted, and a share of $5.8 \%$ were declared repeaters and/ or with the situation unfinished. The highest promotion rate was recorded in full-time and private education. Of course, such quantitative data must also be interpreted qualitatively, in a contextual way. The "successful graduates" indicator is awarded for the category of graduates who, after completing their higher education, have obtained a diploma (for example, bachelor's degree, master's degree, doctoral degree). In 2019, the European Commission's Eurostat Barometer (2020) confirmed the directly proportional correlation between the level of education promoted and employment in the labor market, with a rate of $84.8 \%$ employment at EU level, much higher than the people with a lower level of training who do not hold these certifications.

Most analyzes in the field of literature have focused on predictive or correlational aspects of success in studying, and in some synoptic theoretical substantiations are presented the subordinate themes, inventories of standardized tools for measuring success (in York et al., 2015) or ways to support students to complete their studies, as a maximum level of success and support strategies support performing individual tasks, as a minimum level of success (in Ifenthaler \& Yau, 2020).

Our choice to address a theme related to the contribution that university teachers make to the success of the students started from the fact that universities are seen as essential institutions and organizations, capable and responsible for implementing change. In order to achieve this, improving training is one of the axes of accumulatingon results, through a kind of teaching in accordance with the way learning is done (Biggs \& Tang, 2011). Modern teachers have multiple roles: they are experts in their specializations, initiators and organizers of training situations, responsible for a pleasant socio-affective climate during the activities, they are the people who can motivate or encourage students, facilitators of accessing difficult content, such as coaches are, when they focus on achieving short-term goals, on engaging in solving tasks or mentors, when there is "mutual sharing of formative events, challenges, successes and failures (...)." (Stan, 2004, p. 30)

\section{Theoretical foundation}

What is success? In a well-known definition, achieving school success refers to the acquisition of skills specific to a particular educational level (York and others, 2015). The achieved results (Harackiewicz and others, 2002; Snyder and others, 2002; Tinto \& Pusser, 2006; Tracey and others, 2012, according to York and others, 2015, pp. 13-15) and the institutional persistence, that is the fact that people continue their studies (Inoue-Smith, Y., 2020, p. 52), are the equivalent of training success. Success in studies is correlated or not with high chances of success in life, because the concept of successful life, even happy, is broader, personalized and goes beyond the training activity at a higher level or finding employment.

If in the past, the outcomes of learning were related to performance, as an articulated suite of proposed and achieved goals, with a minimum and maximum level of accomplishment of tasks, now education is concerned with skills training, through a mobilization of cognitive resources, which guide decision and action (Perrenoud, 2001; Delaunay, 2006). In our opinion, the success of the students must be considered the situation of having competencies, developed as solutions to problems, by activating a set of knowledge, skills and attitudes (De Ketele, 1996, according to Manolescu, 2010). 


\subsection{Priority internalist explanations}

Garcia (2001) included among the competencies involved in academic success, as adaptation to this environment - the ability of the students to selfregulate, that is the degree to which they actively participate in the learning process. Self-regulation is specific to students (Zimmerman, 2002), and in the context of online training, which is becoming more and more pronounced in higher education, such a perspective is all the more desirable. Starting from their own expectations, Bandura and Adams (1977) focused on self-efficacy, in the sense of one's belief in the possibility of performing behaviors that will produce the expected results. The perception of selfefficacy has an impact on obtaining results. We deduce that the self-confident aspect can also be transferred in the case of success in the gradual approach of study disciplines and continuous or final evaluations.

In the model of global success, Crețu (2009) showed that internal factors are essential for the manifestation of excellence. The multivariate analysis made by the authoress, the bond with the axiological plan, understanding the concept as an individualized construct, with impact on personal life, highlights the need to socio-emotionally support and capitalize on the efforts of gifted people, by advising them. From another perspective, according to Kappe and van der Flier (2012), in achieving success in studies, conscientiousness has proven to be a much more important factor than intelligence.

\subsection{The double determination of success}

Some studies have shown a directly proportional relationship between the communication skills of the teachers, understood as supportive communication, favourable to academic success, by increasing the results (Khan and others, 2017). The personal characteristics of the students maintain their dominant role, therefore, the effectiveness of teachers (Khurshid, 2014), following the collaboration with students, is an important variable, which is yet located in the background, being framed in "the institutional support" (Khurshid, 2014, p.45). It is, therefore, recommended that teachers provide their students with the socio-affective support or the inspirational model, that follow certain extracurricular activities. The student-centered approach is characterized by the presence of innovative teaching-learning-assessment methods, which aim to promote learning through communication with the teachers and other students involved in the learning process. These pathways consider the students to be active participants in their own learning, developing transferable skills, such as problem solving, critical thinking, and reflective thinking (Attard, Di Iorio, Geven \& Santa, 2010, p. 7). Through these, the focus on students also meets academic success.

When referring to visible learning, Hattie (2009) argued that school should be built on what needs to be learned, if it is to continuously gather evidence of this learning and use this data to better meet the needs of learners, through systematic training and to improve the collective and individual professional practice of teachers. Therefore, designing teaching according to learning styles and adapting to the interests, requirements, difficulties of the students is also an opportunity to contribute to their academic success. We note that, even in the case of the students who come from disadvantaged socio-economic backgrounds, the teacher comes with real help in achieving success (Osman, Ydhag \& Månsson, 2020). The fact that learning, as a complex activity, is determined by several factors, makes exactly the way the variables combine and influence it to determine the level of success (Mogonea \& Mogonea, 2018).

An interesting model of academic success, proposed by York and others (2015), summarizes the main aspects with which it correlates (Figure 1) and confirms that it is necessary to consider the perspective of the students on this aspect, which aims at directly. Academic success is closely related to: academic achievement, satisfaction, acquisition of skills and competencies, persistence, attaniment of learning outcomes, career success (see Figure 1).

Figure 1. Revised Conceptual Model of Academic Success (York, Gibson \& Rankin, 2015, p.5)

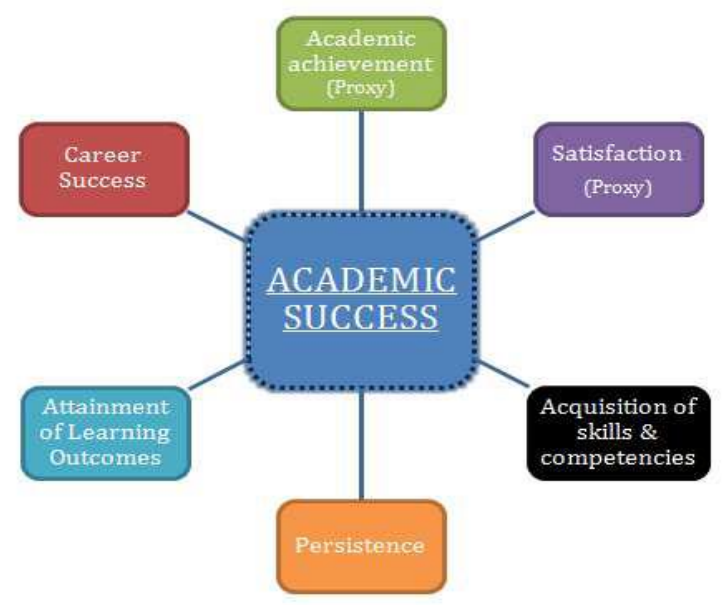

Taking into account the need for persistence and completion of studies, the concept we adhere to is that 
student success is doubly determined, important in terms of human resources being: motivation, effort, capitalization of personal qualities, which students must be aware of and use effectively, as well as opportunities for external support, from teachers or other significant colleagues.

\section{Research methodology}

3.1. Assumptions. Our research-action strategy, focused on qualitative tools, was built around the hypothesis that: For a successful learning, students must have created the well-being, that mental pattern or setting in which they accept and enjoy learning. In higher education, especially reorganized online, the situation depends on both them and the important pedagogical factors: teachers, through technical support, guidance, encouragement, the way they communicate and relate to them, through the suggestions and adjustments that appear after the evaluation. Thus, the students overcome the initial resistance/insecurity, participate in activities, apply the teachers' recommendations, maintain an intrinsic motivation in the long run.

3.2. Sample of subjects and content. In the academic activities within the training program for the teaching profession of a sample of 111 students from the University of Craiova, the approach of general education and classroom management gave us the opportunity to discuss how the causes of academic success are attributed, to find out what the evaluations are in relation to what the teachers offer them. Due to the specifics of the specialization of studies and the training as future teachers with specializations in the field of Foreign Languages (English, French - main), the sample included, mostly females $(78 \%)$. The disciplines Fundamentals of pedagogy. Curriculum theory and methodology; The theory and methodology of training, The theory and methodology of evaluation, respectively The management of the class are fundamental, obligatory disciplines, in the curriculum of the students who are doing their initial psychopedagogical training for semesters 2,3 and 5 of studies, but they go in their specialization through at least 12 other fundamental disciplines, specialized and optional, so they have a curriculum rich in disciplines and in number of hours.

3.3. Methodology used. We were interested in how teachers intervene and provide help, as people with responsibilities for organizing training and harmonizing academic relationships. Therefore, we aimed to know the students 'perception about the extent to which teachers' interventions contribute to their results in the study programs. The research was conducted through: organizing focus groups (Krueger \& Casey, 2005), introducing formative-experimental measures, and then, using the semantic differentiator, adapted from Osgood and others (1957), accompanied by analysing promotion in exams in the academic year 2020-2021. These approaches were applied to students in the first, second and third years of undergraduate studies. We resorted to an adaptation of the semantic differentiator with the intention of measuring, at a subconscious level, the appreciation of some concepts related to academic success, in a variant that is as easy and fast as possible for the subjects included in the sample (1=very much for the positive adjective; $2=$ much for the positive adjective; $3=$ a little for the positive adjective; $4=$ medium; $5=$ a little for the negative adjective; $6=$ much for the negative adjective; $7=$ very much for the negative adjective). Thus, the questions in the questionnaire verified the following aspects: if their teachers assessed them correctly and gave them feedback at the end of the first semester; if the students are satisfied with the quality of the didactic communication; if they had the feeling of belonging to the academic environment; if their teachers guided them to success.

\section{Results obtained}

4.1. In the case of focus groups, the responses received referred to the following:

- Because they passed the exams in the first semester, the students considered that they were successful in learning, and the conditions for their success were: planning, perseverance, analysis of the formulated tasks, actions to solve them, reflections for improvement. A difficult situation, which was invoked by the students, for whom they needed guidance, was how to better manage their effort and time, in the conditions of online activity.

- In identifying the causes of the occasional learning failures, most students listed the internal causes: poor learning, underestimation of the importance and difficulty of the subject, their superficiality in approaching it. We notice that the assignment of causes was more internal. Very few students explain their success in external positions, acknowledging that their learning effort was small, but the exam subjects were easy.

- In most cases, the alternation of success and failure depends on the interest in the educational subject and the willingness to make the required 
efforts. The students showed that the learning activity is an unpleasant activity, due to the constraining character it involves, when the contents are difficult and voluminous.

4.2. As a result of the focus group discussions, the students who were part of the natural sample, with whom we carried out teaching activities, were guided to become aware and get more support from their teachers during the second semester and at the end of it, when they are demotivated or fail to learn, by intensifying communication, by asking for feedback. As learning progress is staged, the request to reflect (Light \& Cox, 2001) and to establish the essential criteria/ requirements for completing written and applied work was a measure that they agreed on and which the students followed.

4.3. In the case of the students in our sample, the minimum understood success, as persistence, participation and solving tasks, also illustrated as graduation rate in exams was $89 \%$ of the total number of students.

After the exams, in the post-test stage, the majority frequency of students valuing aspects related to the four dimensions proposed by us, through the Osgood scale, had the following configuration (Tables 1-4):

\begin{tabular}{ccccccccccc}
\hline Adjective & $\begin{array}{c}\text { The } \\
\text { value 1 }\end{array}$ & $\begin{array}{c}\text { The } \\
\text { value } 2\end{array}$ & $\begin{array}{c}\text { The } \\
\text { value } 3\end{array}$ & $\begin{array}{c}\text { The } \\
\text { value } 4\end{array}$ & $\begin{array}{c}\text { The } \\
\text { value } 5\end{array}$ & $\begin{array}{c}\text { The } \\
\text { value } 6\end{array}$ & $\begin{array}{c}\text { The } \\
\text { value } 7\end{array}$ & Adjective & $\begin{array}{c}\text { The total } \\
\text { number }\end{array}$ & $\begin{array}{c}\text { The number whith } \\
\text { maximum frequency }\end{array}$ \\
\hline Sweet & 8 & 29 & 23 & 21 & 14 & 12 & 4 & Bitter & 111 & 29 \\
\hline Good & 11 & 26 & 28 & 24 & 15 & 6 & 1 & Bad & 111 & 28 \\
\hline Correct & 7 & 31 & 27 & 21 & 14 & 8 & 3 & Incorrect & 111 & 31 \\
\hline Beautiful & 9 & 27 & 30 & 21 & 16 & 4 & 4 & Ugly & 111 & 31 \\
\hline Active & 7 & 31 & 27 & 21 & 14 & 7 & 4 & Passiv & 111 & 111 \\
\hline Strong & 10 & 26 & 25 & 21 & 16 & 7 & 6 & Weak & 26 \\
\hline Coherent & 10 & 26 & 23 & 22 & 17 & 8 & 5 & Incoherent & 111 \\
\hline Simple & 9 & 21 & 23 & 22 & 26 & 7 & 3 & Complex & 111 & 26 \\
\hline Warm & 10 & 23 & 25 & 21 & 17 & 13 & 2 & Cold & 111 \\
\hline Bright & 10 & 23 & 25 & 21 & 17 & 14 & 1 & Dark & 111 \\
\hline
\end{tabular}

Legend: $1=$ very much for the positive adjective; $2=$ much for the positive adjective; $3=$ a little for the positive adjective; $4=$ medium; $5=\mathrm{a}$ little for the negative adjective; $6=$ much for the negative adjective; $7=$ very much for the negative adjective.

From a socio-emotional point of view, success can be experienced subjectively, appreciated by the students themselves or it can be recognized, felt unanimously, from the outside, evaluated by evaluating teachers, other evaluators, colleagues. Making a correct assessment and giving feedback is useful for differentiating between real and false success stories. Moreover, the cases of true failure are delimited, compared to false failures. Consequently, it can be assessed, depending on the consistency, complexity of the evaluation, whether the success is situational or general, episodic or lasting.

Table 2. Didactic communication

\begin{tabular}{cccccccccccc}
\hline Adjective & $\begin{array}{c}\text { The } \\
\text { value 1 }\end{array}$ & $\begin{array}{c}\text { The } \\
\text { value 2 }\end{array}$ & $\begin{array}{c}\text { The } \\
\text { value 3 }\end{array}$ & $\begin{array}{c}\text { The } \\
\text { value } 4\end{array}$ & $\begin{array}{c}\text { The } \\
\text { value } 5\end{array}$ & $\begin{array}{c}\text { The } \\
\text { value } 6\end{array}$ & $\begin{array}{c}\text { The } \\
\text { value } 7\end{array}$ & Adjective & $\begin{array}{c}\text { The total } \\
\text { number }\end{array}$ & $\begin{array}{c}\text { The number whith } \\
\text { maximum frequency }\end{array}$ \\
\hline Sweet & 8 & 16 & 25 & 30 & 18 & 10 & 4 & Bitter & 111 & 30 \\
\hline Good & 8 & 29 & 24 & 20 & 14 & 12 & 4 & Bad & 111 & 29 \\
\hline Correct & 10 & 23 & 26 & 13 & 20 & 12 & 7 & Incorrect & 111 & 26 \\
\hline Beautiful & 10 & 22 & 25 & 14 & 11 & 19 & 10 & Ugly & 111 & 25 \\
\hline Active & 11 & 30 & 25 & 14 & 12 & 14 & 5 & Passiv & 111 & 30 \\
\hline Strong & 10 & 22 & 22 & 28 & 8 & 14 & 7 & Weak & 111 & 28 \\
\hline Coherent & 10 & 21 & 24 & 10 & 31 & 7 & 8 & Incoherent & 111 & 31 \\
\hline Simple & 20 & 31 & 23 & 10 & 17 & 7 & 3 & Complex & 111 & 31 \\
\hline Warm & 13 & 29 & 25 & 20 & 10 & 12 & 2 & Cold & 111 & \\
\hline Bright & 9 & 29 & 24 & 21 & 15 & 12 & 1 & Dark & 111 & 29 \\
\hline
\end{tabular}

Legend: $1=$ very much for the positive adjective; $2=$ much for the positive adjective; $3=$ a little for the positive adjective; 4 = medium; $5=\mathrm{a}$ little for the negative adjective; 6 = much for the negative adjective; 7 = very much for the negative adjective.

The module/common value for this component was 2 (much for the positive adjective). Generally, the students' perceptions, the satisfaction they experience after obtaining results determine the perceptions, expectations and strategies of their teachers. Mutual feedback evolves like a "snowball." Feedback has effects on improving the motivational status and increasing social interactions. With the development of the level of preparation of the students, they stated that they identified, with the help of the teachers, perspectives for the implementation in practice of the acquired experiences. An important formulated 
comment was the students' desire to be evaluated not necessarily in a stimulating manner, but as objective as possible.

The most frequent attribution for this component of didactic communication was 2 (much for the positive adjective). The promotion of modernized communication, in which the students are partners and active participants in their own learning, develops their transferable skills, such as: problem solving,

Table 3. Experiencing the feeling of belonging to the university environment

\begin{tabular}{|c|c|c|c|c|c|c|c|c|c|c|}
\hline Adjective & $\begin{array}{c}\text { The } \\
\text { value } 1\end{array}$ & $\begin{array}{c}\text { The } \\
\text { value } 2\end{array}$ & $\begin{array}{c}\text { The } \\
\text { value } 3\end{array}$ & $\begin{array}{c}\text { The } \\
\text { value } 4\end{array}$ & $\begin{array}{c}\text { The } \\
\text { value } 5\end{array}$ & $\begin{array}{c}\text { The } \\
\text { value } 6\end{array}$ & $\begin{array}{c}\text { The } \\
\text { value } 7\end{array}$ & Adjective & $\begin{array}{l}\text { The total } \\
\text { number }\end{array}$ & $\begin{array}{l}\text { The number whith } \\
\text { maximum frequency }\end{array}$ \\
\hline Sweet & 9 & 26 & 27 & 23 & 15 & 7 & 4 & Bitter & 111 & 27 \\
\hline Good & 11 & 26 & 28 & 24 & 15 & 7 & 0 & Bad & 111 & 28 \\
\hline Correct & 12 & 23 & 22 & 22 & 25 & 6 & 1 & Incorrect & 111 & 25 \\
\hline Beautiful & 18 & 21 & 20 & 24 & 21 & 5 & 2 & Ugly & 111 & 24 \\
\hline Active & 11 & 17 & 29 & 22 & 17 & 11 & 4 & Passiv & 111 & 29 \\
\hline Strong & 11 & 17 & 29 & 22 & 17 & 11 & 4 & Weak & 111 & 29 \\
\hline Coherent & 10 & 17 & 26 & 25 & 27 & 4 & 2 & Incoherent & 111 & 27 \\
\hline Simple & 14 & 21 & 28 & 25 & 14 & 6 & 3 & Complex & 111 & 28 \\
\hline Warm & 14 & 23 & 26 & 24 & 13 & 9 & 2 & Cold & 111 & 26 \\
\hline Bright & 14 & 24 & 23 & 22 & 12 & 10 & 6 & Dark & 111 & 24 \\
\hline
\end{tabular}

Legend: $1=$ very much for the positive adjective; $2=$ much for the positive adjective; $3=$ a little for the positive adjective; $4=$ medium; $5=$ a little for the negative adjective; $6=$ much for the negative adjective; $7=$ very much for the negative adjective.

The students, who considered that they have the feeling of belonging to our institution, stated that they feel integrated into an environment where there is a requirement to study. They stated that they are proud of the region they belong to, that they adhere to its goals, specificity, traditions. At the socio-emotional level, they feel understood by their teachers and colleagues, they interact positively with them. The most frequent attribution of the students' appreciations for experiencing the feeling of belonging to the university environment was 3 (a little for the positive adjective). Descriptively, the affiliation comes from a connection with the spaces, the materials they meet at the university, in a curricular or extracurricular

Table 4. Orientation towards academic success

\begin{tabular}{cccccccccccc}
\hline Adjective & $\begin{array}{c}\text { The } \\
\text { value 1 }\end{array}$ & $\begin{array}{c}\text { The } \\
\text { value 2 }\end{array}$ & $\begin{array}{c}\text { The } \\
\text { value } 3\end{array}$ & $\begin{array}{c}\text { The } \\
\text { value } 4\end{array}$ & $\begin{array}{c}\text { The } \\
\text { value } 5\end{array}$ & $\begin{array}{c}\text { The } \\
\text { value } 6\end{array}$ & $\begin{array}{c}\text { The } \\
\text { value } 7\end{array}$ & Adjective & $\begin{array}{c}\text { The total } \\
\text { number }\end{array}$ & $\begin{array}{c}\text { The number whith } \\
\text { maximum frequency }\end{array}$ \\
\hline Sweet & 9 & 21 & 28 & 23 & 21 & 8 & 1 & Bitter & 111 & 28 \\
\hline Good & 10 & 21 & 24 & 25 & 23 & 6 & 2 & Bad & 111 & 25 \\
\hline Correct & 10 & 21 & 23 & 25 & 24 & 6 & 2 & Incorrect & 111 & 25 \\
\hline Beautiful & 11 & 22 & 22 & 26 & 24 & 5 & 1 & Ugly & 111 & 26 \\
\hline Active & 9 & 21 & 27 & 23 & 21 & 8 & 2 & Passiv & 111 & 27 \\
\hline Strong & 9 & 21 & 27 & 23 & 21 & 9 & 1 & Weak & 111 & 27 \\
\hline Coherent & 8 & 22 & 24 & 26 & 21 & 8 & 2 & Incoherent & 111 & 26 \\
\hline Simple & 9 & 21 & 23 & 26 & 20 & 8 & 4 & Complex & 111 & 26 \\
\hline Warm & 10 & 23 & 25 & 21 & 16 & 14 & 2 & Cold & 111 & 26 \\
\hline Bright & 11 & 22 & 26 & 22 & 18 & 8 & 4 & Dark & 111 & 26 \\
\hline
\end{tabular}

Legend: $1=$ =very much for the positive adjective; 2 = much for the positive adjective; $3=$ a little for the positive adjective; $4=$ medium; $5=\mathrm{a}$ little for the negative adjective; 6 = much for the negative adjective; 7 = very much for the negative adjective. context, but, especially, with the people. Although they were spatially separated, the sense of belonging to the academic environment was created by the informal interest in their experiences, sustained involvement in various formal activities, synchronous or asynchronous participation in courses, seminars, laboratory activities, homework solving, technical support in accessing modern training platforms, the flow of guidance on preparing and taking exams, which made them invest effort in continuing their studies, to consider their teachers and colleagues close, due to the proactive, assertive, enthusiastic attitude of others. critical thinking and reflexivity. The students reported guidance from their teachers, as highly specialized
peopere people, for the difficult topics. The teachers intervened to reorganize the contents, making them accessible. The students' suggestion for this aspect focused on organizing the communication, showing that it would be necessary to be more coherent, varied, involving more, not only those who stand out. 
The overall value given most often for this component was 3.5 (between a little for the positive adjective and medium). The students' learning interests are diverse, and in a dual version they appear as choices between: an instrumental orientation, for those who learn from strictly pragmatic needs, being motivated from the outside (at the insistence of the family) and a deep orientation, based on intrinsic motivation, towards long-term acquisitions, for those who want to assert excellence, through learning. The first orientation, with extrinsically activated interests, predisposes to a superficial approach to learning, based on reproduction and, it is true, a small part of the students is satisfied with promotion, as a sufficient level of appreciation from the teachers. Most of the students wanted to get the best result. Orientation towards in-depth learning is desirable, as an orientation towards success. The students who adhered to the conception that success is a maximum achievement, appreciated those teachers who formulated, at the beginning of the activity, differentiated objectives and, through perseverance, maintained a culture of quality, communicated their standards, the possibilities for improvement, managing to be convincing to assume these values, progressively.

Beyond the inherent methodological limitations of the assessment scale instrument, whose responses revolved around the central trend or those of the sampling that had a small number of subjects, the general assessment we were able to formulate, starting from the quantitative data in the previous tables show that, in essence, the students with a specialization in Foreign Languages are satisfied with the evaluation and feedback of their teachers, with the way they communicate in the university environment (Tables 1 and 2). They confirmed to us that teachers have a strong influence in the relationship with university students.

The other two components - experiencing the feeling of belonging and the orientation towards academic success have, in the students' appreciation, average but lower values (Table 3 and 4). Perceptions can be explained by the complexity of the context in which they were made, the specifics of the distance learning situation through technology, being one in which the sense of academic belonging has endured the change of physical environment, students participating from home. Consequently, orientation towards success was indirect, being done through training platforms, which, in turn, have a strictly behavioral design, undifferentiated in value. Regardless of the grade received by the students, in the subjects, they considered that the interaction with the teachers had the role of orienting them towards an attitudinal model characterized by intellectual and moral autonomy, promoting a democratic relationship in the university environment.

It can be concluded that teachers contribute to the success of training through empathic interaction, through behaviors that promote the responsibility and independence of the students.

\section{Discussions}

Especially in the first year of studies, the need to guide students towards learning success is confirmed by Sava and others (2015, p. 2), who showed that, ,although the dominant opinion of the students about adapting to academic life, to the educational offer is positive, however, the main difficulties they face are related to adapting to the specifics of higher education in terms of the teaching-learning pace and the information volume management, greater awareness on the part of teachers who teach the students about these difficulties being necessary, to support them in managing them, preventing their demotivation, failure or even abandonment". A similar questionnaire, about the motivation of students to adapt to the university environment (Pleşca, 2017) claimed that, certainly, the positive interaction with the teachers contributes to a better adaptation to the academic life, to a better integration in the rhythm of student life. Our study proves that, even if the students are in the middle of the study program, they confirm the need to be guided by their teachers when participating in the actual activity or in order to prepare for the exams. The final year students follow the teachers' feedback, which confirms their correctness, the completeness of what they have learned, the quality of the applied research or the final works, where the teachers are their coordinators. In the analysis of the learning process, from a theoretical and practical point of view, the motivational-affective factors of learning cane be considered more important than the cognitive ones, for the energetic role they have. Learning depends both on the desire and willingness to learn, the sustained achievement of learning, as well as on the external feedback, which is accompanied by the satisfaction received after the effort. According to Neacşu (2006, p. 10), by stimulating learning autonomy, students themselves can "identify the implicit and explicit relationships between the different theoretical, 
metatheoretical and procedural-methodological components of university studying, academic progress and success, orientation towards successful careers", and teachers should reflect on how they can help them study more deeply, more systematically, more actively.

In order to achieve academic success, Creţu (coordinator, 2019), had in mind the creativity manifestation of the learners, as a skill stimulated in the didactic interactions. This could be a way for the teacher to manifest his role, especially because the practice of critical and creative learning will be transferred to solve a wide range of situations: social and personal (Frăsineanu, 2005). Stimulating participation by implementing application tasks, including the use of new information technologies (Ilie, 2016), formative assessment, which supports learning (Havnes and others, 2012) are components that are associated with the students' persistence in performing tasks.

It is interesting to note that objectivity is pursued more intensely by the interested party in a direct way by the promotion aspect, that is by the evaluated one (and not by the evaluator). Objectivity in evaluation is obtained when the appreciation of the results reflects them undistorted, with impartiality and realism, regardless of the conscience and will of those involved, the resulting assessments being independent of personal opinions, beliefs, interests and dispositions, for the time being, and the objective evaluation was one of the students' wishes, repeatedly expressed. We can look at this action of searching for objective landmarks, through connection with others, as a metacognitive exercise, in which the adjustment stage is important, an exercise subsumed by an evolutionary, dynamic process, such as success in learning.

We overcome the unilateralism related to the responsibility of the students regarding success in higher education, the quantitative way of dealing with this subject, because quality training also includes the beneficiary's perception of the factors that ensured its success. The approach as success or achievement versus unsuccess, failure, initiated and supported by teachers, will have adaptive implications for the next stage that students will go through, either when they decide to continue their studies or as graduates, when integrating professionally.

\section{Conclusions}

Undoubtedly, as recommended by the educational policy documents in Romania or abroad, the quality of the teachers 'activity contributes to improving the students' results (whether young or adult), but after establishing the mechanisms by which it can be achieved, what matters are the experiences relevant for the students, their appreciation. The pursuit and success actions require human resources - teachers their students - and they negotiate, establish agreements, empower, co-evolve, synchronize when they act to have results together. We argue that, if at the beginning of studies, it is useful to have a professional and study orientation, focused on optimal, appropriate options, to guide students in the specifics of the university environment, during or at the end of their studies, the pursued criteria should be well clarified, there should be made progress analyzes, so that the requirements can be maintained, and the students can accept and face them. The cognitiveaffective errors that both students and teachers have in connection with success, with the roles of educational factors, such as extension of generalizations, exaggerations of attribution, excessive relativization, subjective interpretation, fatalism, pessimism, criticism, attitudes to avoid interaction should be acknowledged, but especially avoided. It is useful to convert negative attitudes into constructive, mobilizing, resolute manifestations. We advocate for: the need for contextual, differentiated assessment, the importance of interpersonal knowledge and respect for individual rhythms, focusing on critical-constructive approaches, highlighting the balance of achievements and failures, with establishing the aspects that should be improved in teaching, learning, assessment, relationships, management.

Although, the lack of time is often invoked, the teachers counseling and informing of the students, promoting successful models outside of classes, seminars or laboratories are actions that can be exploited by the beneficiaries of the teaching act.

\section{Authors note:}

Ecaterina Sarah Frăsineanu is an associate professor, with a Phd in Educational Sciences, at the Department of Teacher Training, University of Craiova. In addition to her didactic activity in the initial and continuous training of teachers, she carries out research activities and educational projects, as a 
member of the Center for Psychopedagogical Research. Her research interests include: university didactics, the self-management of effective learning in students, improving communication in education, modernizing training through pedagogical constructivism, interculturalism at educational level.

Vali Ilie is an associate professor, with a Phd in Educational Sciences, at the Department of Teacher Training, University of Craiova. She carries out teaching activities and participates in institutional projects, as well as in research activities, as a member of the Center for Psychopedagogical Research. Her areas of expertise refer to: teaching styles, the cognitive-constructivist paradigm in education, the application of management and leadership, sociological approaches in education; school as an organization, the socio-emotional development of students and teachers.

\section{References}

Attard, A., Di Iorio, E., Geven, K., Santa, R. (2010). Student centered leaning. Ghid pentru studenţi, cadre didactice şi instituţii de invăţământ superior. Avaiable at: www.anosr.ro/wp-content/.../07/2012-Toolkit-ICScadre-didactice1.pdf (accessed at 13.05.2021).

Bandura, A., Adams, N., E. (1977). Analysis of SelfEficaccy Tehory of Behavioral Change. Cognitive Therapy and Research, VoL 1, No. 4, pp. 287-310. Avaiable

at: ink.springer.com/content/pdf/10.1007/BF01663995.pdf (accesed at 21.04.2021).

Biggs, J., Tang, C. (2011). Teaching for quality learning at university: What the student does. 4-th Edition. McGrawhill.

Crețu, C. (2009).Global Success and Giftedness. In Gifted Education. International Handbook. Balchin T., Hymer Barry, Matthews, J.D. (eds.). London: Routledge International Companion. pp.169-176.

Crețu, D.M.(coord.) (2019). Predarea și învățarea în învățământul superior: aspecte teoretice şi practice. Bucharest: Universitară Publishing House.

Delaunay, M. (2006). Connaisances et competences. Avaiable at: http://www.acnantes.fr:8080/peda/disc/eps/idees/rev8_1.htm (accessed at 15.05.2021).

Frăsineanu, E. S. (2005). Evaluarea capacităţii de înțelegere, de interpretare critică şi a competenței de a rezolva situaţii reale manageriale. In Strategii constructiviste în formarea iniţială a profesorului. E. Joiţa (coord.), Ilie, V., Novac, C., Frăsineanu, E.S., Popescu, A.M., Mogonea, F. R., Ştefan, M. A., Mogonea,
F., Boboilă, C. Craiova: Universitaria Publishing House. pp. 361-376.

Hattie, J. (2014). Invățarea vizibilă. Ghid pentru profesori. Bucharest: Trei Publishing House.

Havnes, A., Smith, K., Dysthe, O., Ludvigsen, K. (2012). Formative Assessment and Feedback: Making learning visible. In Studies in Educational Evaluation. 38 (1). pp. 21-27.

Ilie, V. (2016). How to stimulate future teacher-students to participate in specific instructive-educational activities. In Journal Plus Education. Vol. XVI. Octomber. pp. 271-288.

Ifenthaler, D., Yau, J. Y.K. (2020). Utilising learning analytics to support study success in higher education: a systematic review. In Education Technology Research Development. 68: pp. 1961-1990. Avaiable at: https://doi.org/10.1007/s11423-020-09788-z (accesed at 21.04.2021).

Inoue-Smith, Y. (2020). Factors in Success among University Students. In Micronesian Educator \#28. A Journal of Research, Theory, and Practice in Guam and Micronesia. (Editors: Y. Inoue-Smith, C. Schreiner). School of Education, University of Guam. pp.47-56.

Kappe, R., van der Flier, H. (2012). Predicting academic success in higher education: what's more important than being smart?. In European Journal of Psychology of Education. Vol. 27. pp. 605-619.

Khan, A. , Khan, S., Zia-Ul-Islam, S., Khan, M. (2017). Communication Skills of a Teacher and Its Role in the Development of the Students' Academic Success. In Journal of Education and Practice.Vol.8. No.1. pp. 1821.

Khurshid, F. (2014). Factors Affecting Higher Education Students' Success. In Asia Pacific Journal of Education, Arts and Sciences. Vol. 1. No. 5. Pp. 39-47.

Krueger, R.A., Casey, M.A. (2005). Metoda Focus Grup: ghid practic pentru cercetarea aplicată. Iasi: Polirom Publishing House.

Light, G., Cox, R. (2001). Learning and teaching in higher education: the refflective professional. London: Paul Chapman.

Manolescu, M. (2010). Pedagogia competenţelor - o viziune integratoare asupra educaţiei. În Revista de pedagogie. Nr. 58 (3). pp. 55-66.

Mogonea, F., Mogonea, F. R. (2018). Requirements and modalities of ensuring success in academic learning. In Educatia 21 Journal. 16 (1). pp. 49-63. Avaiable at: DOI: 10.24193/ed21.2018.16.06 (accessed at 03.06.2021).

Neacşu, I. (2006). Învățarea academică independentă. Ghid metodologic. Bucharest: Universităţii din București Publishing House.

Osgood, C.E., Suci, G., Tannenbaum, P. (1957). The measurement of meaning. University of Illinois Press.

Osman, A., Ydhag, C.C., Månsson, N. (2020). Recipe for educational success: a study of successful school performance of students from low social cultural 
background. In International Studies in Sociology of Education. Avaiable at: DOI: 10.1080/09620214.2020.1764379 (accessed at 17.05.2021).

Perrenoud, P. (2001). La compétence comme mobilisation située

de ressources cognitives guidant la décision et l'action. Avaiable from: http://www.unige.ch/fapse/SSE/teachers/perrenoud/php_ main/php_2001/2001_33.html\#Heading1(accessed at 21.04.2021).

Pleșca, M. (2017). Motivaţia de adaptare a studenţilor la mediul universitar. În Volumul Conferinței Probleme ale ştiinţelor socioumanistice şi modernizării învăţământului. Chișinău, Seria 1. Vol. 19. pp.81-88.

Sava, S., Bunoiu, M. Lucheș, D., Malița, L. (2015). Adaptarea studenților din anul I la viata academică. În Volumul celei de a II-a Conferințe Naționale de Cercetare in Educație. Iași.

Sălăvăstru, D. (2004). Psihologia educației. Iasi: Polirom Publishing House.

Schomburg, H. (2007).The Professional Succes of Higher Education Graduates. In European Journal of Education.Vol. 42, No. 1, pp.35-37.

Stan, E.(2004). Pedagogie postmodernă. Iasi: Institutul European Publishing House.
York, T. T., Gibson, C., Rankin, S. (2015). Defining and Measuring Academic Success, In Practical Assessment, Research, and Evaluation. Vol. 20. Article 5. Avaiable at: https://doi.org/10.7275/hz5x-tx03 (accessed at 19.04.2021).

Zimmerman, B.J. (2002). Becoming a self-regulated learner: An overview. In Theory Into Practice. 41 (2). pp. 64-70. Avaiable at: DOI: 10.1207/s15430421tip4102_2 (accessed at 31.05.2021).

***Comisia Europeană. (2020). Eurostat. Statistici anuale privind ocuparea forței de muncă. Avaiable at : https://ec.europa.eu/eurostat/statistics-

explained/index.php?title=Archive:Employment_statisti cs/ro\&oldid=496085 (accessed at 04.06.2021).

***Ministerul Educației Naționale. (2018). Raportul public privind starea învățământului superior din România, 2017-2018.

Avaiable at: https://www.edu.ro/sites/default/files/Raport\%20privind \%20starea\%20\%C3\%AEnv\%C4\%83\%C8\%9B\%C4\%83 m\%C3\%A2ntului\%20superior\%20din\%20Rom\%C3\%A 2nia_\%202017\%20-2018.pdf (accessed at 24.05.2021).

*** Ministerul Educației Naționale. (2011). Legea Educației Naționale nr. 1, actualizată 2020. Avaiable at: https://edu.ro/sites/default/files/_fi\%C8\%99iere/Legislatie /2020/LEN_actualizata_octombrie_2020.pdf (accessed at 17.05.2021). 